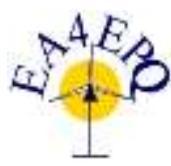

International Conference on Renewable Energies and Power Quality (ICREPQ'14)

La Coruña (Spain), 25 ${ }^{\text {th }}$ to $27^{\text {th }}$ March, 2015

Renewable Energy and Power Quality. Tournal (RE\&PQJ)

ISSN 2172-038 X, No.13, April 2015

\title{
Photovoltaic powered irrigation system applied to familiar agriculture
}

\author{
Chilundo, R. J. ${ }^{1}$, Carvalho, Paulo C. M. ${ }^{1}$; Diniz, M. M. N. ${ }^{2}$; Bezerra, A. M. E. ${ }^{3}$ \\ ${ }^{1}$ Electrical Engineering Department \\ Federal University of Ceará \\ Campus do Pici - 60455 - 760 Fortaleza/CE (Brasil) \\ Phone/Fax number: +55(85) 33669585/74, e-mail: rosychil@yahoo.com.br, carvalho@dee.ufc.br \\ ${ }^{2}$ Instituto Joazeiro de Desenvolvimento Sustentável \\ Rua Barão do Rio Branco, No 1071, sl. 1021, 60025-061 Fortaleza/CE (Brasil): \\ e-mail: magilce@hotmail.com \\ ${ }^{3}$ Fitotechny Department \\ Federal University of Ceará \\ Campus do Pici - 60440 - 560 Fortaleza/CE (Brasil) \\ Phone number: +55(85) 33669671, e-mail: esmeraldobezerra@ yahoo.com.br
}

\begin{abstract}
This paper aims to analyze the technical and financial feasibility of a stand-alone photovoltaic powered irrigation system applied to a familiar production unit. The agricultural unit was installed in the Center for Teaching and Research in Urban Agriculture (NEPAU), which operates in partnership with the Alternative Energy Laboratory (LEA), both located at the PICI campus of the Federal University of Ceará. The unit occupies a floor area of $134 \mathrm{~m}^{2}$, with a water reservoir that simulates a pond, lake or well with capacity of 3534 liters, a 12 VDC pump motor and a photovoltaic module of $135 \mathrm{Wp}$. The efficiencies of photovoltaic module, pump and global set were $8.4 \%, 42 \%$ and $3.5 \%$, respectively. The assumed service life is 25 years and the capital returns after 9,3 years.
\end{abstract}

\section{Key words}

Photovoltaic pumping, irrigation, familiar agriculture

\section{Introduction}

In a world facing environmental questions like the climate change, renewable alternative sources of energy are a key tool for developed and developing countries.

In most of the developing countries a significant part of the population has no access to conventional electricity grid and no reliable drinking water supply for human consumption [1]. Additionally, the cost of the electricity needed for irrigation is high, a crucial element to the continuous and stable food and raw materials production [2].

In this context, this paper aims to experimentally analyze the technical and financial feasibility of a photovoltaic (PV) powered irrigation system as a component of a Center of Sustainable Food Production. The center aims to disseminate knowledge in the areas of technological innovations to eradicate poverty and hunger, familiar agriculture, generation of employment and income and environmental preservation.

\section{Energy and agriculture}

The productive use of energy consists in the exploitation of energy for activities that improve the economic income and the well-being of people [3]; in this way, the success of the agricultural practice is strictly dependent on energy availability.

The agricultural activity is centered in energy transformation processes, as a fundamental variable to provide integrity to the agronomic growth. The energy is used for irrigation, machinery drive, processing and conservation of agricultural products and other forms of exploitation of energy resources in agricultural production [4].

In the 19th century, Japan and the United States have adopted practical policies to support the features and technologies involved in agricultural production. This strategy has boosted the rapid development of cultivated and irrigated areas in these countries, taking agricultural activities to high levels [5].

\subsection{Subsistence agriculture}

Agriculture is the set of human actions that serve to transform the natural environment in a way suited for the development of crops [6]. The activity is basically classified into two principal groups:

- $\quad$ subsistence agriculture and

- market agriculture.

The subsistence agriculture is practiced in areas smaller than 2 hectares and the most applied irrigation techniques 
are: surface, aspersion or sprinkler and localized [7]. According to data from the Brazilian Institute of Geography and Statistics (IBGE) [8], 82.9\% of the field hand labor of the Brazilian Northeast region is represented by family farmers.

\subsection{Photovoltaic pumping system}

Water pumping systems are classified according to the energy source that powers the system and the technical characteristics of the system; there are basically five types of pumping systems used in irrigation of crops [5]: a) photovoltaic (PV) pumping systems;

b) wind pumping systems;

c) pumping systems connected to the conventional power grid;

d) pumping systems powered by internal combustion engines;

e) manual pumping systems.

PV pumping systems generally consist of an area of PV modules, motor - pump unity, power conditioning system (drive, pump controller) and storage system (optional). These systems are specially designed for pumping water from wells, ponds, rivers and reservoirs and are similar to conventional systems, with the basic difference that the pump motor drive is made by PV modules.

\section{Sizing parameters of $P V$ pumping systems}

For Fedrizzi [9], regardless of the tool used for the PV pumping sizing, at least the following parameters must be defined, even if only for estimates:

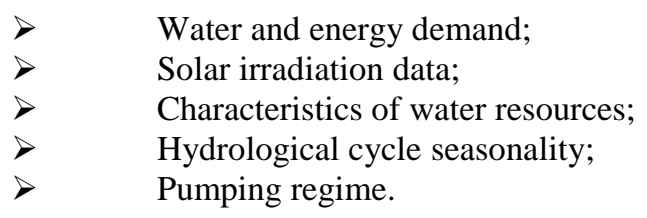

Hydraulic power depends on the daily water flow and total head [10]:

$$
P_{h}=2.725 * Q_{d} * H_{M T}
$$

$>$ Qd - daily flow designed $\left(\mathrm{m}^{3}\right)$

$>\mathrm{H}_{\mathrm{MT}}$ - total manometric height $(\mathrm{m})$

$>\mathrm{P}_{\mathrm{h}}-$ hydraulic power $[\mathrm{W}]$

\section{Electric motor power}

$$
P=\frac{P_{h}}{\eta_{M P}}
$$

$$
\mathrm{P} \text { - Electric motor power [W] }
$$$$
\eta \mathrm{MP} \text { - Pump efficiency [\%] }
$$

\section{Solar power over the area of the PV module}

$$
H=G^{*} A_{M}[W]
$$

- $\mathrm{G}-$ Global solar irradiance $\left[\mathrm{W} / \mathrm{m}^{2}\right]$

- $\mathrm{A}_{\mathrm{M}}$ - Useful area of the PV module $\left[\mathrm{m}^{2}\right]$

\section{Efficiencies}

The overall efficiency of the PV pumping system was calculated in 3 steps, according to Equations 4, 5 and 6:

\section{1) PV Module Efficiency}

$$
\begin{aligned}
\eta_{F V} & =\frac{P}{G * A_{M}}=\frac{V * I}{G^{*} A_{M}} * 100 \\
\text { - } & \mathrm{V}-\text { Voltage [V] } \\
\text { - } & \mathrm{I}-\text { Current }[\mathrm{A}] \\
\text { - } & \eta_{\mathrm{FV}}-\mathrm{PV} \text { module efficiency }[\%]
\end{aligned}
$$

2) Motor pump Efficiency

$\eta_{M B}=\frac{P_{h}}{P} * 100$

\section{3) Overall efficiency}

$\eta_{G}=\frac{P_{h}}{G * A_{M}} * 100$

$$
\text { - } \eta_{\mathrm{G}}-\text { Overall efficiency [\%] }
$$

To meet the water demand of the production unit, a minimum irradiance is required for the used $135 \mathrm{Wp} \mathrm{PV}$ module [11]. In this way, the minimum irradiance $\left(G_{\min }\right)$ was calculated using:

$$
G_{\min }=\frac{P_{\min } * G_{\text {padrao }}}{P_{M}}
$$

$\mathrm{P}_{\min }$ is the minimum power required for the system to operate in the desired conditions, $\mathrm{G}_{\text {padrão }}$ the standard global solar irradiance $\left(1000 \mathrm{~W} / \mathrm{m}^{2}\right)$ and $\mathrm{P}_{\mathrm{M}}$ the maximum PV power output.

\section{Materials and methods}

For the analysis of the unit were used the analytical method of calculation and the experimental method. The financial analysis was performed by the method of internal rate of return (IRR) and the analysis of the cash flow. The analysis of cash flow was performed to assess the investment time of return using the computational tool RETScreen [12].

The production unit occupies a floor area of $134 \mathrm{~m}^{2}$, with a reservoir of water that simulates a pond, lake or well with capacity of 3534 liters, a 12 VDC motor - pump and a $135 \mathrm{Wp} \mathrm{PV}$ module. According to Fig. 1, the measurements include: water flow, pressure, voltage, current and solar irradiance. The nominal motor power is $55 \mathrm{~W}$ and pump output pressure is 14 psi. 


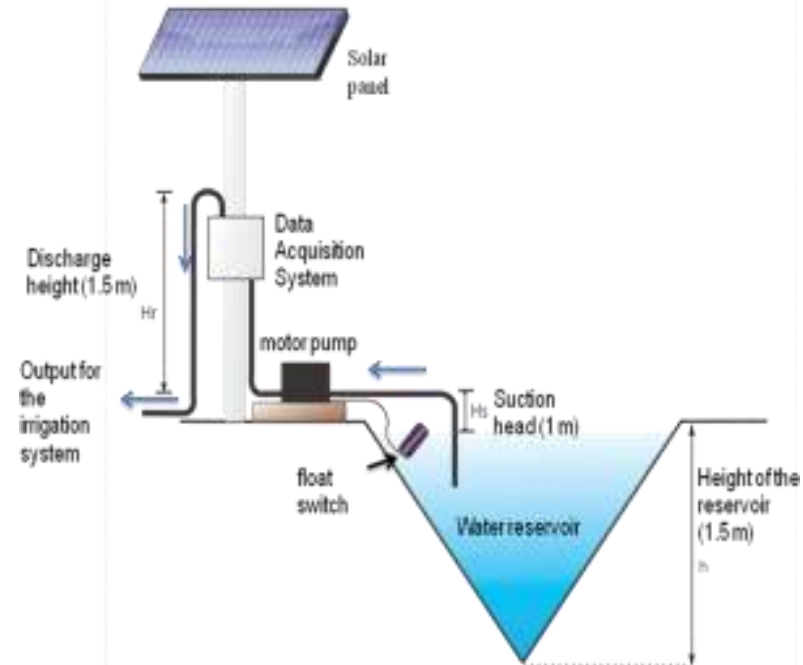

Fig.1. Diagram of the PV powered pumping system

For data acquisition, a RTF pyranometer / $82-05$, a SU7000 flow sensor, a pressure sensor PN2024, current and voltage sensors were used. The control and data acquisition is made by the SanUSB system and data transmission by the Wi-Fi system [13]. SanUSB is a computational tool for data acquisition using microcontrollers; the tool has low-cost components found in the Brazilian market and has free access (Fig. 2).
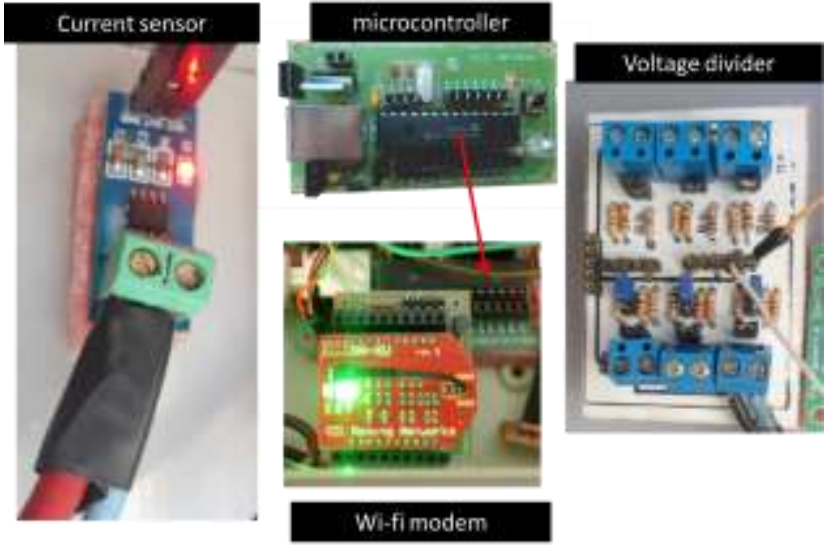

Fig.2. SanUSB system and data transmission

The irrigation system consists of 24 micro-sprinklers with a working pressure between 10 to 20 feet of water column, distributed uniformly along the circular beds (Fig. 3). Twelve micro-sprinklers installed along the sidelines are operated simultaneously, each at a pressure of $14 \mathrm{psi}$, with an average flow of $0.9 \mathrm{l} /$ minute for sunny days; for cloudy days three micro-sprinklers are operated simultaneously with a pressure of 15.3 psi and flow of $1.1 \mathrm{l} /$ minute. The choice of circular beds was due to some advantages such as a better cultivation area use, water efficiency for irrigation and creation of green and harmonious environments in rural and urban areas.

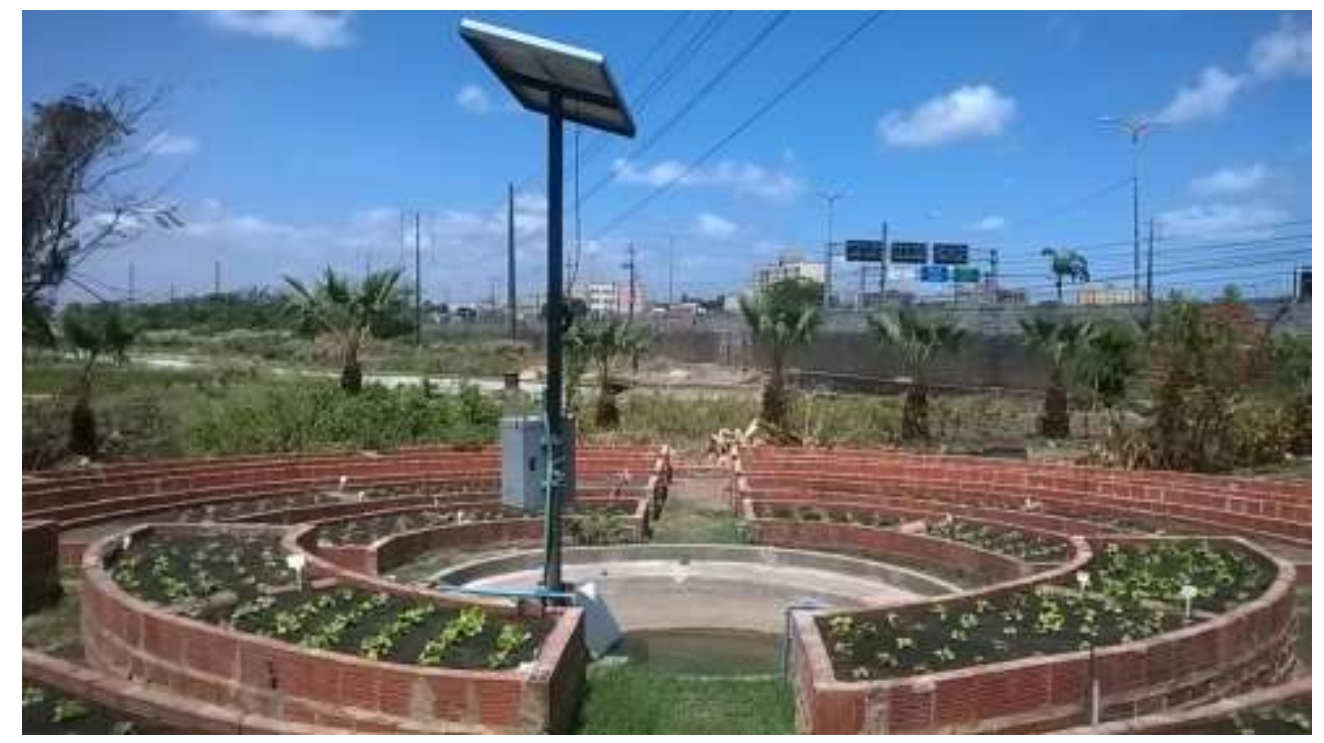

Fig.3. PV powered irrigation system applied to familiar agriculture

\section{Results and discussion}

The PV plant has the capacity to pump water during the hours of sunshine throughout the day. Figures 3 and 4 show irradiance, flow and pressure values in a cloudy and in a sunny day, respectively.
Irradiance, flow and pressure data were collected during the coriander production cycle in August and September 2014; in a second phase, the days were classified in sunny and cloudy days. 


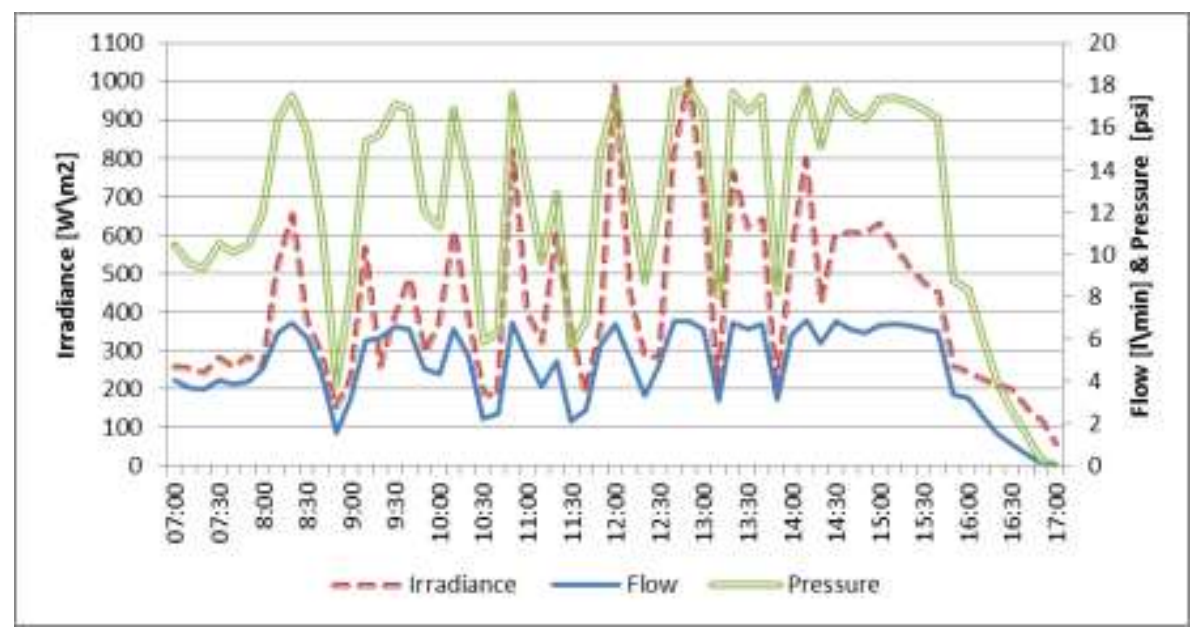

Figure 3: Irradiance, flow and pressure values in a cloudy day

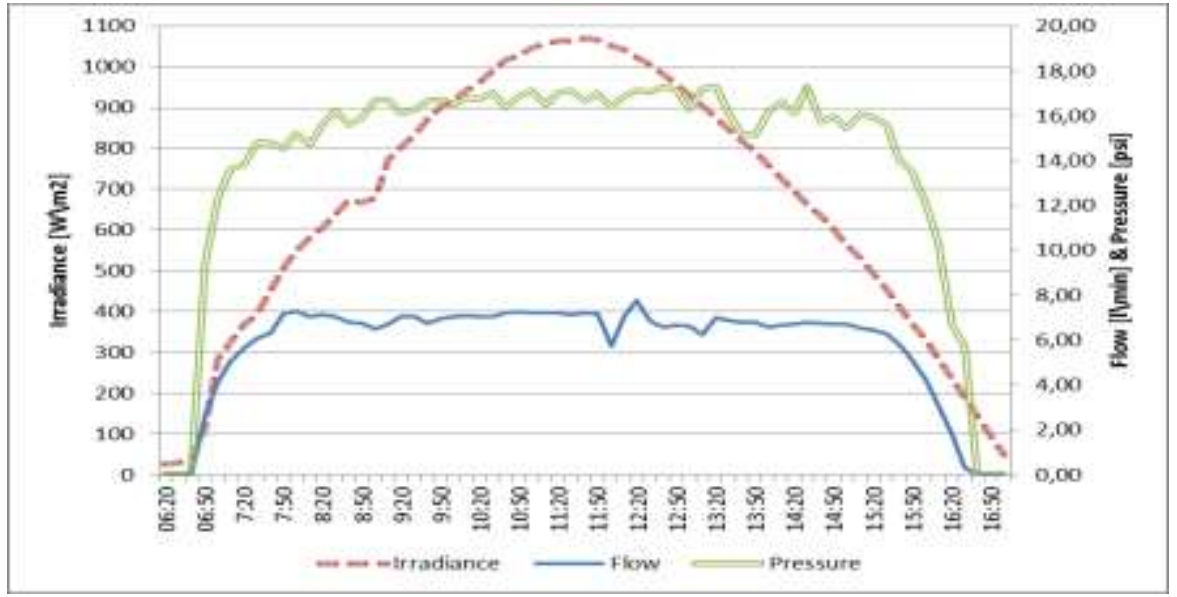

Figure 4: Irradiance, flow and pressure values in a sunny day

On September 9, 2014 (cloudy day), the flow and pressure curves followed the irradiance; solar irradiation was $4.3 \mathrm{~kW} / \mathrm{m}^{2} /$ day, a volume of 2850 liters was pumped and the average flow was $4.751 / \mathrm{min}$ with an average output pressure of 12.2 psi.

On September 15, 2014 (sunny day), solar irradiation was $7.04 \mathrm{kWh} / \mathrm{m}^{2} /$ day, a volume of 3973 liters was pumped and the average flow was $6.51 / \mathrm{min}$ with an average pressure of 15.4 psi.

For irrigation of coriander, the unity daily water demand was 1600 liters in the area of $134 \mathrm{~m}^{2}$.

\section{PV pumping system efficiency}

The obtained efficiencies are summarized in table 1 .

Table 1: Obtained efficiencies

\begin{tabular}{cc}
\hline & Efficiency (\%) \\
\hline PV module & 8.4 \\
Motor pump & 42 \\
Overall & 3.5 \\
\hline
\end{tabular}

\section{Financial analysis and cash flow}

The cost of the PV modules and accessories and the lack of benefits provided by the PV generation in a country like Brazil, with high level of solar irradiation, are still barriers to the mass use of the technology. Advances are recorded in incentives for microgeneration and distributed minigeneration and power compensation systems (Normative Resolution 482, April 17, 2012, of the National Electric Energy Agency - ANEEL).

In the present analysis, the input variables were the monthly mean irradiation values over a year in Fortaleza, $\mathrm{PV}$ module tilt angle, electricity price [R $\$ / \mathrm{MWh}$ ] for Ceará and defined by ANEEL and motor pump and PV generator initial costs.

Figure 5 illustrates that the cash flow becomes positive after 9,3 years of plant operation, considering a lifetime of 25 years and an internal rate of return of $12.5 \%$. 


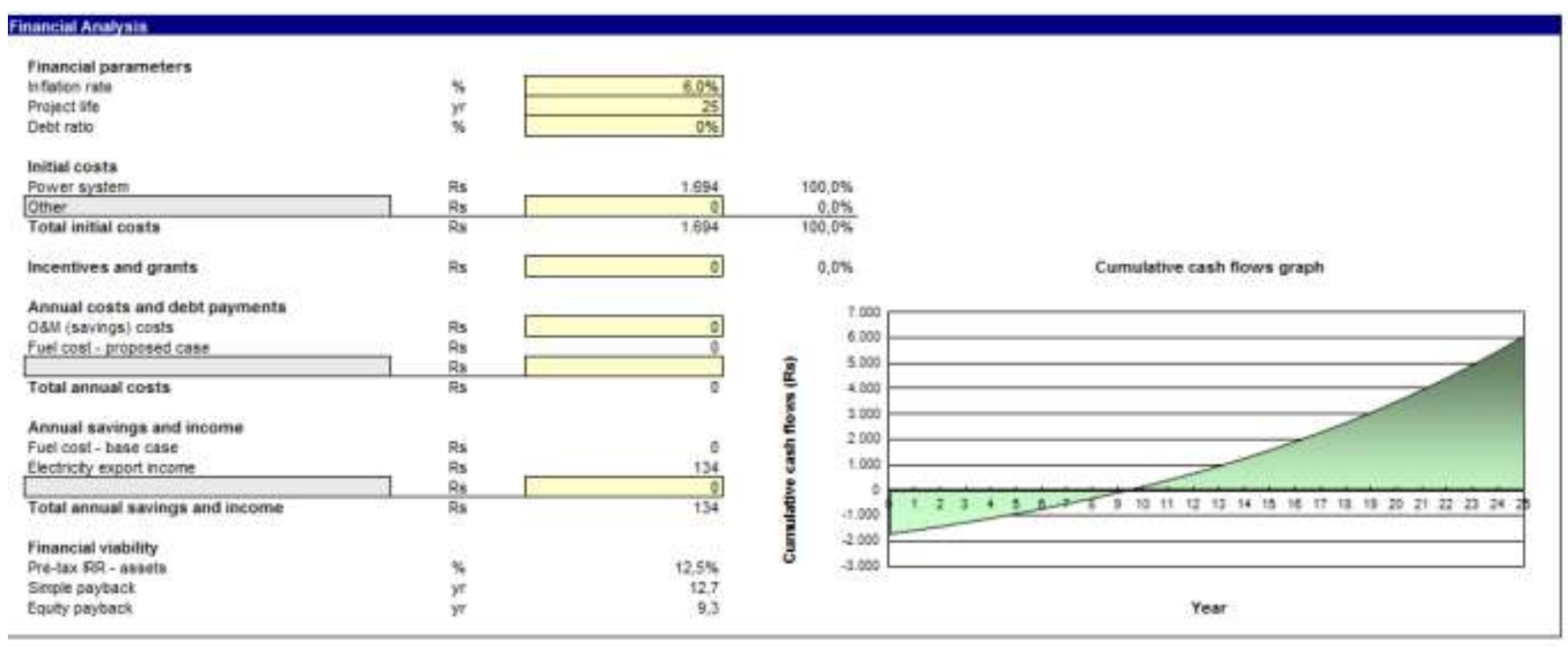

Figure 5: Cash flow

\section{Conclusions}

Considering technical issues, some operational conditions of the pumping and irrigation systems need to be guaranteed to adequately meet the unit demand, such as electric power and pump pressure. The results show that, using a $135 \mathrm{Wp}$ PV module, a solar irradiance of $407 \mathrm{~W} / \mathrm{m}^{2}$ is necessary to ensure an electric power of 55 $\mathrm{W}$ and a pressure of $14 \mathrm{psi}$. In this way, a measured mean solar irradiance of $645 \mathrm{~W} / \mathrm{m}^{2}$ is enough to supply the load.

The use of circular beds allowed to save 3608 liters of water during cultivation of $69 \mathrm{~kg}$ of coriander, which was equivalent to the economy of $1.6 \mathrm{kWh}$ of electrical energy compared to a cultivation system with conventional beds.

In the present study, the invested capital returns after 10 years, considering and internal rate of return of $10.2 \%$.

\section{Acknowledgements}

CAPES for the scholarship given to the first author;

$\checkmark \quad$ PETROBRAS for the financial support.

\section{References}

[1] Chilundo R. J.; Carvalho, P. C. M.; Mahanjane, U.S. Potencial da Tecnologia Fotovoltaica para Irrigação de Unidades de produção Familiar: Estudo de Caso para Moçambique. V CBENS. Recife (2014).

[2] AGÊNCIA MANDALLA. Projecto de Produção Integrada Mandalla. file:///C:/Users/Abel/Downloads/apostila_mandalla.pdf. (2012).

[3] KAPADIA, K. Produtive Uses of Renewable Energy: A Review of Four Bank - GEF Projects. http://www.eci.ox.ac.uk/publications/downloads/kapadia 04-consultancy.pdf., 1-33. 2004.
[4] TANJI, K. K. \& YARON, B. Managment of water use in agriculture. Advanced series in agricultural sciences: 22, 1-320. 1994.

[5] STANHILL, G. 1984. Energy and agriculture. Spring Heidelberg New York Tokyo, Berlim.

[6] ANDRADE, C. L. T. Seleção do Sistema de Irrigação. Embrapa Milho e Sorgo. 1-16. 2001. Sete Lagoas - Minas Gerais, Embrapa.

[7] INSTITUTO BRASILEIRO DE GEOGRAFIA E ESTATÍSTICA. Censo Agropecário 2006. Resultados Preliminares.

http://www.ibge.gov.br/home/estatistica/economia/agrop ecuaria/censoagro/2006/agropecuario.pdf., 1-146. 2007. Rio de Janeiro, Instituto Brasileiro de Geografia e Estatística. 19-9-2014.

[8] VALER MORALES L. R. 2011. A Utilização de Sistemas Fotovoltáicos de Bombeamento para Irrigação em Pequenas Propriedades Rurais. Universidade de São Paulo. Mestrado Energia: 5 - 170.

[9] FEDRIZZI M. C. 2003. Sistemas Fotovoltaicos de abastecimento de água para uso comunitário: Lições apreendidas e procedimentos para potencializar sua difusão. Universidade de São Paulo. Doutorado .pp 201.

[10] ODEH I., YOHANIS Y. G. \& NORTON B. 2006. Influence of pumping head, insolation and PV array size on PV water pumping system performance. Solar Energy 80: $1,51-64$.

[11] OLIVEIRA R. S. H. 2011. Planta laboratorial de dessalinizaão via osmose reversa alimentada por energia 
solar fotovoltaica com ou sem baterias. Universidade Federal do Ceará. Mestrado 1 - 196.

[12] MINISTRY OF NATURAL RESOURCES CANADA. RETScreen software, online user manual. www.retscreen.net.

[13] JUCÁ S. C. S. 2014. Desenvolvimento de sistemas de aquisição de dados sem fio aplicados à microgeração descentralizada. Universidade Federal do Cerá. Tese de doutorado. 